\title{
WILD GRAZING OF BEEF CATTLE IN THE BUFFER VILLAGE OF SPTN REGION II SUMBERWARU BALURAN NATIONAL PARK
}

\author{
Siti Azizah, Irfan H. Djunaidi, Jaisy Aghniarahim Putritamara, Achadiah \\ Rachmawati, Rositawati Indrati, Zazin Fahresi Alamanda and Deby Okta \\ Pradana \\ Faculty of Animal Science, Brawijaya University, Indonesia \\ E-mail: siti.azizah@ub.ac.id*,irjuna@ub.ac.id, achadiahr@ub.ac.id, \\ rindrati29@ub.ac.id, jaisyap@ub.ac.id, zazinfahresi@student.ub.ac.id, \\ debyot71@gmail.com
}

\begin{tabular}{|c|c|}
\hline ARTI & ABSTRACT \\
\hline $\begin{array}{l}\text { Received: } \\
\text { November, 26th } \\
2021 \\
\text { Revised: } \\
\text { December, 17th } \\
2021 \\
\text { Approved: } \\
\text { December, 19th } \\
2021\end{array}$ & $\begin{array}{l}\text { Baluran National Park faces public pressure in the form of } \\
\text { illegal grazing, which threatens the preservation of flora and } \\
\text { fauna in it. This study aims to analyze illegal grazing activities } \\
\text { that threaten the conservation efforts of Baluran National Park } \\
\text { in Sumberwaru Village, Asembagus district, Situbondo. Data } \\
\text { collection was carried out from April to June } 2021 \text { with a } \\
\text { qualitative approach. The data were taken from several key } \\
\text { informants, namely } 3 \text { Baluran National Park officers, the Village } \\
\text { Head of Sumberwaru, the Head of Loka Pasuruan, the } \\
\text { Situbondo Livestock Service, and } 12 \text { extensive semi-intensive } \\
\text { beef cattle breeders. The results showed that the behavior of } \\
\text { illegal grazing was caused by cultural factors that did not } \\
\text { prioritize profit but only as an investment and indicator of } \\
\text { social status. As a result, maintenance management is very } \\
\text { efficient and depends on feed that can be obtained for free by } \\
\text { grazing wildly in the Baluran National Park conservation area. } \\
\text { The solution required is a participatory Collaborative Forest } \\
\text { Management that benefits all stakeholders. }\end{array}$ \\
\hline $\mathrm{K}$ & $\begin{array}{l}\text { Wild Grazing, Livestock Business Behavior, Community } \\
\text { Pressure On Forests, Collaborative Forest Management }\end{array}$ \\
\hline
\end{tabular}

Siti Azizah, Irfan H. Djunaidi, Jaisy Aghniarahim Putritamara,

Achadiah Rachmawati, Rositawati Indrati, Zazin Fahresi Alamanda and Deby Okta Pradana (2021). Wild Grazing of Beef Cattle in the Buffer Village of SPTN Region II Sumberwaru Baluran National Park.

How to cite:

E-ISSN: Journal Eduvest. 1(12): 1443-1450

Published by: 


\section{INTRODUCTION}

The people of Sumberwaru Village, a buffer zone for Baluran National Park for several generations, have integrated and utilized the area around Baluran National Park. It impacts regional management as a conservation area adjacent to community settlements easily accessible from various directions, both land and sea routes. Most of the people around the area still depend on the potential of Baluran National Park in various ways, for example, by looking for firewood, grazing in the wild, harvesting (tamarind, honey, grass, etc.), and poaching (Ridwan, Azizah, \& Kusumastuti, 2018). It includes the community of beef cattle breeders who graze their livestock extensively to enter the conservation area. The impact of this extensive grazing is socially and ecologically disastrous. According to (Nurrani, Bismark, \& Tabba, 2014) and (Adnan, Berliani, \& Hardiyanto, n.d.), economic conditions and social factors (such as status, income, power, customs) of forest communities can be a problem and conflict between various interests.

Developing areas bordering protected areas, especially land use planning, can lead to a shift in utilization towards the operation of national parks. Therefore, it is necessary to restructure the function of the area, increase the value and opportunities of the site, support the preservation of the National Park and contribute to regional development. On the other hand, by offering the possibility of increasing the legal use of local resources, it can serve the interests of terrestrial communities and improve their economic capacity. It combines the economic benefits of the community with the preservation of biodiversity and ecosystems in the national park area, including the construction of a buffer zone outside the national park (Bismark, Sawitri, \& Eman, 2007).

Illegal grazing in Baluran National Park carried out by buffer village communities can have a negative impact on conservation carried out by National Park managers. (Azizah \& Kawedar, n.d.) explain that some of the negative effects caused by illegal grazing are as follows:

1. Social impacts caused by conflicts arise between herders and Baluran National Park managers.

2. Economic impacts: The community gets more benefits because they do not have to think about the cost of feed for their livestock grazing in conservation areas.

3. Ecological impacts, the impacts caused by these activities such as fragmentation of wild animal habitats, the soil turns into compaction, threatens the originality of wild cattle as germplasm and threatens natural vegetation.

Communities around the forest are very dependent on forest resources. However, forest use often leads to forest destruction because the community tries to get the maximum benefit without thinking about the sustainability aspect of the forest (Basir, Dassir, \& Makkarennu, 2020). This study aims to analyze the illegal grazing activities that threaten the conservation efforts of Baluran National Park in Sumberwaru Village, Asembagus district, Situbondo.

\section{RESEARCH METHOD}

The research location is in Sumberwaru Village, Banyuputih District, Situbondo Regency. The selection of the research location was carried out purposively (deliberately), namely the farmers in the hamlet, by considering that the site is directly 
adjacent to a conservation forest. The research took place from April to June 2021.

Data collection uses a qualitative approach by conducting in-depth interviews with 12 key informants or key respondents based on a questionnaire. Another method used is through field observations conducted at the research location to see the actual phenomena. The key informants of this research were three officers of the Baluran National Park, the Village Head of Sumberwaru, the Head of the Pasuruan Loka, the Head of the Situbondo Livestock Service, and 12 extensive and semi-intensive beef cattle breeders.

The data analysis is descriptive qualitative by analyzing, describing, and summarizing several conditions from the data collected in interviews and observation of problems. Data analysis was carried out by data reduction, presentation, conclusion drawing/verification (Miles, Huberman, \& Saldana, 2014).

\section{RESULT AND DISCUSSION}

\section{Overview of Research Sites}

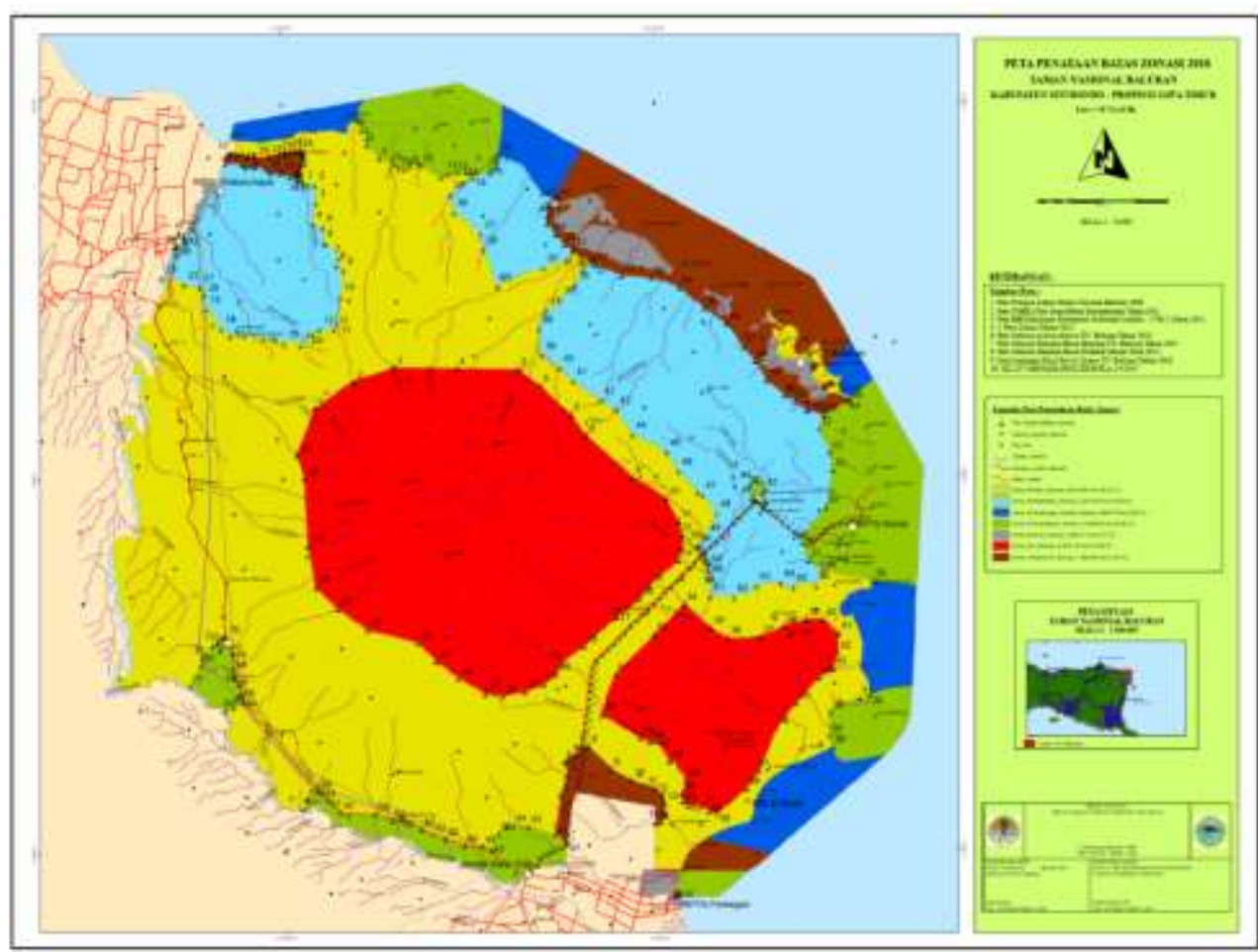

Figure 1. The 2018 Zoning Boundary Map of Baluran National Park, Situbondo Regency - East Java Province

According to data from the Central Statistics Agency in Situbondo Regency (2020), the area of Sumberwaru Village is $111,270 \mathrm{~km} 2$. Sumberwaru Village is located at an altitude of 258 meters above sea level with a tropical climate and temperatures ranging from 27-30 degrees Celsius, as well as being considered an agricultural area with sugarcane as the main crop. In 2019, the population in Sumberwaru Village was 8,252 people with a livelihood as farmers, ranchers, and factory workers. 


\section{Siti Azizah, Irfan H. Djunaidi, Jaisy Aghniarahim Putritamara, Achadiah Rachmawati, Rositawati Indrati, Zazin Fahresi Alamanda and Deby Okta Pradana}

\section{Beef Cattle Wild Herding Behavior}

The people of Sumberwaru Village (or often referred to as Karangtekok Village), occupying the buffer zone of Baluran National Park for several generations, have integrated and utilized the area around Baluran National Park. Most people are farmers, farm laborers, and NTFP users, for example, honey, candlenut, etc. On the other hand, they are beef cattle breeders who graze their livestock extensively. The farmers themselves own a small number of beef cattle, and most of them are noise from the investors. (Azizah \& Kawedar, n.d.) research show that Sumberwaru beef cattle breeders have been herding their livestock for years to increase their income. The majority of Sumberwaru people work as farmers as farm laborers and earn less than Rp. 500,000/per month. Low education and economy force people to herd cattle to the Baluran National Park conservation area to meet their livestock needs. The concept of noise has been passed down from generation to generation and passed down to the next generation. The cattle investors who are accused are mainly from the area around Sumberwaru Village so that the turnover of buying and selling cows only occurs in that village.

Like the culture of beef cattle farming in general in Indonesia, farmers in Sumberwaru Village also position their livestock as investment and social status. The increasing cattle population is due to the high interest of community members who work outside the city and save on cattle. High social status awards are given to farmers by the number of cows owned or given to farmers. It shows the trustworthiness of the rower and his ability as a keeper/breeder. At the same time, the quality of livestock is not an indicator of success as a breeder. Breeders prefer to have many beef cattle with a small profit compared to a relatively small number but provide a large profit.

Herding activities in conservation forest areas have been carried out for generations; even the regulation's prohibition has triggered conflicts between the community and the management of the National Park. The conflict becomes sensitive because there are often misunderstandings and prejudices between the two parties, such as the issue of acacia plants deliberately spread by certain parties. Rights to the forest sometimes overlap, some being claimed by groups that do not even live in the area surrounding the forest. Granting clear land titles under these conditions may be difficult to implement. It may subsequently be unable to resolve some of the problems and conflicts associated with customary rights and resources on the land (ContrerasHermosilla, Fay, \& Effendi, 2005).

The emergence of the cow row system in the Sumberwaru Village community is due to several factors. The main factor is the area's proximity where you can find green fodder for cattle, which is easily accessible by villagers, located on the border with the forest of the Baluran National Park-Conservation Area. The close distance encourages farmers to herd cows owned by residents. Second, there is an emotional closeness between community members such as close friends, relatives, neighbors between investors and rowers. There is a high sense of empathy for the intimacy caused by seeing relatives, neighbors, and close relatives experiencing unfavorable economic conditions. The rowdy pattern gave rise to the initiative to assist in the form of cattle entrusted to their partners, agreeing that the business results were divided between the owners and the cattle breeders. This assistance aims to assist close relatives or relatives in helping increase the family's economic income, which is based on mutual relation and cooperation.

The rowdy system between investors and breeders also significantly affects conservation efforts in Baluran National Park. Fighting rules are very lax, and there is no explicit black-and-white agreement. The distribution of the results is carried out according to the following rules: 
1. The division is carried out in odd years (first, third, fifth, and so on)

2. The first calf of the cattle belongs to the farmer, then alternates with that of the investor

It is very attractive for farmers who do not have to pay for feed, although it is not profitable. The best way to reduce costs is to graze livestock by utilizing conservation land that provides free forage. Thus farmers do not need to pay for feed. Feed is a production factor with the largest expenditure for beef cattle business where feed has a high contribution of around $75 \%$ in production costs.

If there is a risk of noisy cows, the unwritten rule states that the investor is the one who bears the cost of the loss. There is no charge for the cow rower because the risk posed is not due to an element of intent. But in fact, this is not the case; for example, cows are lost in the forest due to being eaten by forest predators or injured leg fractures due to cows walking tiredly over steep rocks so that cows are forced to be sold at low prices. In these cases, the complainant must replace because at the beginning of the agreement, the investor did not ask the rower to maintain and breed intensively and not be released into the wild or grazed into the forest. Although in fact, this illegal grazing is already known by investors.

The resolution of problems that arise is carried out by way of family deliberation between the two parties. Both breeders and investors believe that there is a law of karma, namely that God will repay bad deeds to livestock keepers if they play cheating. The kinship and emotional closeness also cause great compassion and do not have the heart to take legal action, given their excellent relationship so far.

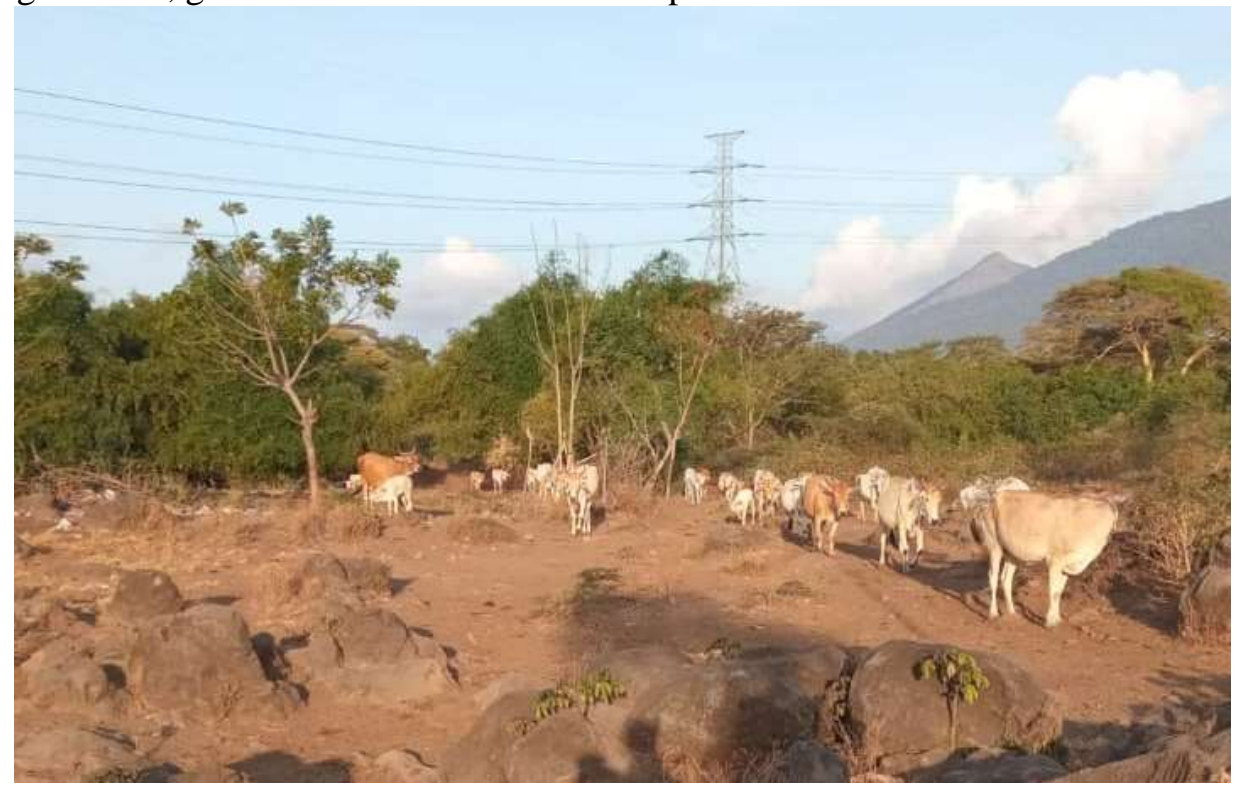

Figure 2. Beef cattle herding in Sumberwaru Village

Illegal grazing is caused by farmers not prioritizing the quality of their cows. They choose to have a large number of cows even though they are in poor condition. Farmers also believe in the rights of living things to natural resources freely. This belief makes cattle farmers feel entitled to enter freely grazing their livestock in the core zone. Government Regulation No. 68 of 1998 states that the core zone functions for ecosystem protection, preservation of unique flora and fauna, and their habitats that are sensitive to disturbances and changes. It has germplasm sources from wild plant and animal species to benefit research and development of science, education, supporting cultivation. Based on government regulations, the core zone is a protected zone, and illegal grazing violates 


\section{Siti Azizah, Irfan H. Djunaidi, Jaisy Aghniarahim Putritamara, Achadiah Rachmawati, Rositawati Indrati, Zazin Fahresi Alamanda and Deby Okta Pradana}

the zoning rules that the Baluran National Park has socialized.

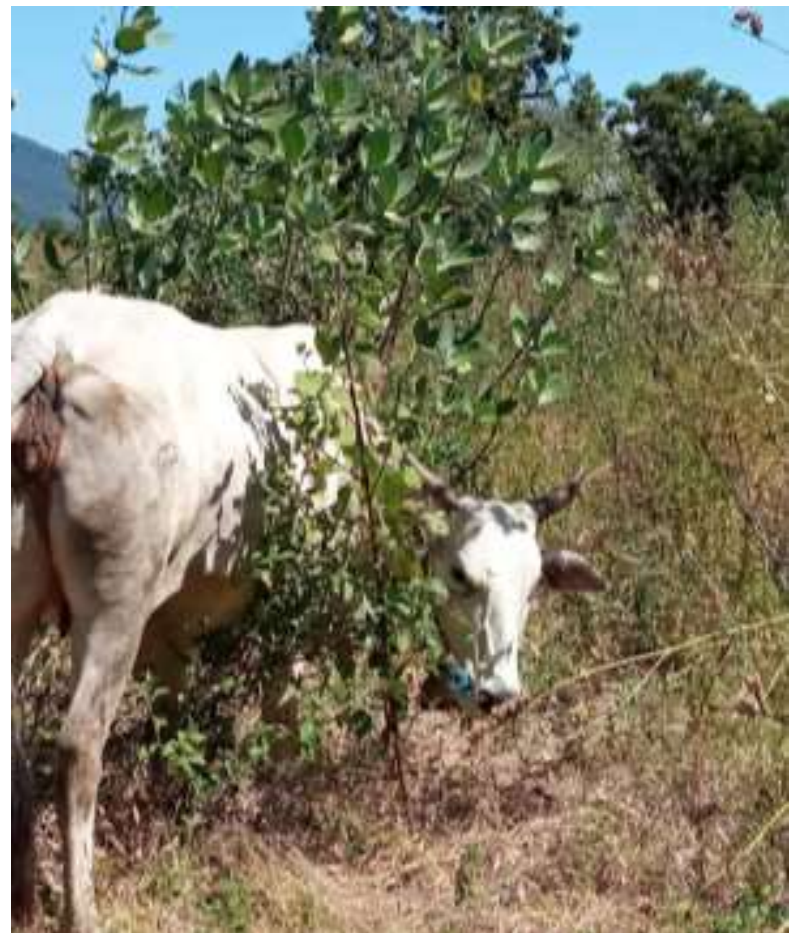

Figure 3. Condition of forage during the dry season

Regarding illegal grazing in protected National Park areas, farmers do not feel they are destroying forests due to their wild grazing. In fact, during the dry season, the home range for cattle grazing will be further into the conservation zone due to the lack of available forage feed. As a result, besides the livestock getting thinner, the damage to the conservation zone is also getting worse. Suppose this illegal grazing activity is allowed to continue. In that case, it will damage the National Park area and enable a livestock business pattern that does not provide profit to business actors.

\section{Efforts to Reduce Public Pressure on Baluran National Park}

Sumberwaru Village is a buffer zone for the Baluran National Park conservation agency. There is more than 4,000 head of cattle kept by the community, of which around 1,600 are grazed to the core zone of Baluran National Park. Various parties have been working together to reduce public pressure on the Baluran National Park conservation area. The following are the efforts made to minimize the damage caused by grazing beef cattle owned by farmers:

1. The introduction of sorghum was piloted in the Labuhan Merak area by the Situbondo Livestock Service in collaboration with the Pasuruan Beef Cattle Research Workshop. The results obtained are still not as expected because farmers then sell sorghum at low prices.

2. Formation of livestock groups which then received assistance from Beef Cattle Lolit, for example, the provision of 25 cows. Constraints to the development of livestock groups and the diffusion of technology mostly lie in the social aspect.

3. Making communal cages as well as introducing concentrates by academics. This activity was also not successful because it contained elements of the concentrate sales business and, in the end, led to conflicts between several parties. 
Based on the experience of efforts that have been made previously, the approach in solving this problem is most appropriate to do with a socio-cultural system before physical development. The program should bring all stakeholders together to have the same vision, mission, and activity objectives. A participatory community development approach is needed so that all parties feel that they contribute to the program that will be carried out. A high sense of ownership of all parties to a program will increase cooperation in achieving physical development success. (Christian, 2019) stated that based on three categories of sustainable forest management by CIFOR, collaborative management should include:

1. Social processes, indicating the extent to which the quality of articulation and communication and the degree of integration and collaborative action.

2. Adaptive natural resource management shows the level of planning, implementation, monitoring, and adjustments made in the management of forest resources. It includes personal, ecological, technical, and financial capacities to implement sustainable management.

3. Impact/conditions of collaboration and adaptive resource management show the expected impacts of collaborative and adaptive management are and how collaborative and adaptive management are implemented.

Proponents of CFM (for example, see Borrini-Feyerabend 1997 and Ghate 2003) argue that CFM benefits local communities because it can conserve forest resources. Since it has socio-economic problems due to the impact of infrastructure, ecology, institutions, and policies on the forestry sector and local communities, ecological effects can affect patterns of resource use and better forest conditions. Economic impacts include a marked increase in local livelihoods from the sale/consumption of forest products or access to forest-based employment opportunities (Turyahabwe, Tumusiime, Byakagaba, $\&$ Tumwebaze, 2013).

\section{CONCLUSION}

Wild grazing is a problem that has existed for years in the Baluran National Park area. It is mainly caused by cultural factors that position cattle as an investment that does not pay attention to livestock business profits and prioritizes the amount of livestock rearing as an indicator of social status. This situation causes farmers not to pay attention to maintenance management and is the most profitable feeding by grazing wildly in the Baluran National Park area. Several attempts have been made to reduce public pressure on Baluran National Park. Still, they have not brought good results, so that in the future, participatory Collaborative Forest Management is needed from all stakeholders.

\section{REFERENCES}

Adnan, H., Berliani, H., \& Hardiyanto, G. (n.d.). Suwito., Sakti, DK (2015). Pemberdayaan Masyarakat Melalui Kemitraan Kehutanan.

Azizah, Siti, \& Kawedar, Yahya Bagus. (n.d.). The effects of farming Beef Cattle on Baluran National Park Conservation (Case Study in Karang Tekok, Banyuputih District, Situbondo Regency).

Basir, Basran Nur, Dassir, Muhammad, \& Makkarennu, Makkarennu. (2020). Peran Struktur Sosial Masyarakat Sekitar Hutan Dalam Pengelolaan Hutan Kemasyarakatan di Desa Betao Riase. Jurnal Hutan Dan Masyarakat, 3948. 
Bismark, M., Sawitri, Reny, \& Eman, Eman. (2007). Pengelolaan dan zonasi daerah penyangga Taman Nasional Gunung Ciremai, Kabupaten Kuningan, Jawa Barat. Jurnal Penelitian Hutan Dan Konservasi Alam, 4(5), 467-483.

Christian, F. Y. (2019). Levelling up the collaborative forest management in Indonesia: a review. IOP Conference Series: Earth and Environmental Science, 285(1), 12008. IOP Publishing.

Contreras-Hermosilla, Arnoldo, Fay, Chip, \& Effendi, Elfian. (2005). Strengthening forest management in Indonesia through land tenure reform: issues and framework for action. Forest Trends Washington DC.

Miles, Matthew B., Huberman, A. Michael, \& Saldana, Johnny. (2014). Qualitative data analysis: A methods sourcebook.

Nurrani, Lis, Bismark, M., \& Tabba, Supratman. (2014). Tipologi penggunaan lahan oleh masyarakat pada zona penyangga Taman Nasional Aketajawe Lolobata di Kabupaten Halmahera Timur. Jurnal Penelitian Sosial Dan Ekonomi Kehutanan, 11(3), 29121.

Ridwan, Ahmad, Azizah, Siti, \& Kusumastuti, Anie Eka. (2018). Persepsi Pengunjung Terhadap Agrowisata Sapi Perah Nusa Pelangi Di Kabupaten Malang. Jurnal Master Pariwisata (JUMPA), 5(1), 57-76.

Turyahabwe, Nelson, Tumusiime, David Mwesigye, Byakagaba, Patrick, \& Tumwebaze, Susan Balaba. (2013). Impact of collaborative forest management on forest status and local perceptions of contribution to livelihoods in Uganda. Journal of Sustainable Development, 6(10), 36. 